\title{
Regional Financial Development, Firm Heterogeneity and Investment Efficiency*
}

\author{
Ruonan Zhang ${ }^{1}$, Hong Yin ${ }^{2}$ \\ Received : July 5, 2018 Revised: August 12, 2018 Accepted: October 10, 2018
}

\begin{abstract}
The purpose of this paper is to examine the relationship between regional financial development and corporate investment efficiency as well as the relationship between firm-level characteristics and corporate investment efficiency. Using a large sample of A-listed companies in China from CSMAR database between 2003 and 2016, this paper explores corporate investment efficiency and its influencing factors in emerging market on the basis of heterogeneous stochastic frontier model. The results show that: (1) the average investment efficiency of Chinese listed companies is $74.5 \%$, and the investment efficiency of large enterprises, state-owned enterprises and enterprises with relatively high financial development level is significantly higher; (2) compared with average corporate investment efficiency in the year 2003, the investment efficiency of different types of enterprises in 2016 is significantly higher, and the gap is gradually widening; (3) enterprise heterogeneity namely firm size, nature of property right, and institutional environment reflected by the level of regional financial development indirectly affects corporate investment efficiency by influencing the financing constraints and uncertainty. The findings suggest that to improve corporate investment efficiency in emerging market, financial market should be accelerated, regional balance should be restored and the differences among regions, industries and differences between public and private sectors should be eliminated.
\end{abstract}

Keywords: Financial Development ; Investment Efficiency ; Financing Constraints ; Heterogeneous Stochastic Frontier Model.

JEL Classification Code: D21; 016; 031

\section{Introduction}

The nineteenth National People's Party of China clearly pointed out that China will deepen reform in an all-round way. Comprehensively deepening reform involves many fields and many aspects. Among them, the financial market as an organic part of the market economy plays an important role in the development of commodity economy. Although the current financial reform in China has achieved some achievements, there are still many problems waiting

* This paper was supported by talent introduction project of Suzhou Vocational University.

1 First Author, Assistant Professor, Department of International Trade, Business School, Suzhou Vocational University, Suzhou, China, Tel: +86-158-9557-0299, E-mail: zhrn3700@163.com

2 Corresponding Author, Associate Professor, Department of Accounting, Business School, Suzhou Vocational University, Suzhou, China,

Tel: +86-151-8228-1601, E-mail: yinhongcdlg@163.com to be resolved. Therefore, the deepening of the structural reform of the supply side in the financial field is the most important part of the current work of Chinese government. It is also necessary to study the role of financial development in promoting regional economic growth.

Through heterogeneous stochastic frontier model, the article explores the impact of regional financial development on economic growth and company's micro behavior from the perspective of financing constraint theory. The results show that financing constraints are still an important factor affecting the investment efficiency of listed Companies in China. Compared with average corporate investment efficiency in the year 2003, the investment efficiency of sample enterprises increased by about $5.48 \%$ in 2016, with an average investment efficiency of 0.770 , but there is still a gap of $20 \%$ over the target value. Second, the heterogeneity of companies represented by company size and nature of property right and regional financial development level which reflects the difference of institutional environment, are the key variables that affect financing constraints. Third, 
although the investment efficiency of different types of enterprises increased in 2016 compared to that in 2003, the gap is gradually widening. Compared with small and medium-sized enterprises, non-state owned enterprises and enterprises in lower level of financial development, large enterprises, state-owned enterprises and enterprises with higher level of financial development are more efficient in investment. This shows that the enterprise heterogeneity and the institutional environment of the enterprise affect the investment behavior and efficiency of the enterprises by influencing the financing constraints and financing uncertainty, and ultimately affect the regional economic growth.

The present study contributes to the literature in a number of ways. First, this article examines the impact of regional financial development on enterprises' investment behavior from a micro perspective, and enriches the literature in the field of regional financial development. Second, the article focuses on the evolution and influencing factors of the investment efficiency of listed companies in China from a long-term longitudinal perspective, and enriches the literature in corporate investment efficiency. Third, this article uses the heterogeneous stochastic frontier model to explain the factors that affect the financing constraints of listed companies in China. From both institutional environment and enterprise heterogeneity perspectives, we discuss the impact of financing constraints on enterprises investment behavior, which provides an incremental contribution to the development of financing constraint theory.

Our findings have great practical significance. As a special transitional economy, China's capital market is less developed, with unbalanced economic structure, varying financing cost for listed companies and serious financing constraints especially for private sectors. In order to alleviate financing constraints, policymakers and the government should actively improve the information environment of listed companies, broaden the financing channels and promote regional financial development. This paper demonstrates the impact of regional financial development on the micro behavior of companies and provides support for the value of the financial system and mechanism in improving corporate investment efficiency and optimizing the allocation of resources.

The remainder of the paper is structured as follows: Section 2 reviews the extant literature and puts forwards the research hypothesis. Section 3 presents the research method. Section 4 analyzes the results. The last section of the paper summarizes its key findings and discusses the limitations.

\section{Literature Review and Research Hypothesis}

Corporate investment behavior and investment efficiency have always been hot topics in the field of corporate finance. Since Fazzari, Hubbard, and Peterson (1998) pioneered in using group test methods to test the impact of financial constraints on corporate investment behavior, many domestic and foreign scholars have begun to pay attention to the impact of financial constraints on corporate behavior, and try to use different grouping methods and model designs for empirical test, coming up with different conclusions.

Hansen (1999) uses the panel threshold model to discuss the relationship between corporate financial constraints and investment behavior. He distinguished the financing constraints of the enterprise by taking the enterprise's debt ratio instead of the dividend payment rate as an alternative index. He finds that there are two threshold values and the financing constraints have changed with time. At the same time, the enterprises that are more financially constrained exhibit significantly greater sensitivities than enterprises that are less financially constrained.

Cleary (1999) uses a multiple discriminant analysis method and constructs the Z-score model to distinguish the degrees of corporate financial constraints. It is found that the higher the corporate reputation (Z-score value), the more sensitive is corporate investment to internal capital, that is, corporates with lower financing constraints are more sensitive to investment cash flow.

Taking 4794 firms from 36 countries in the year 19881998 as a sample, Love (2003) empirically tests the relationship between financial development and regional economic growth. His findings show that in countries with less developed financial systems, companies usually face more serious financing constraints, distorting its investment behavior. Financial development can help ease the financing constraints, leading to regional economic growth.

Almeida (2004) uses a sample of manufacturing firms between 1971 and 2000 and studies the relationship between financial constraints and the cash flow sensitivity of cash. They find that the cash flow sensitivity of cash is positive and significantly different from zero for constrained firms and smaller companies tend to have lower information transparency and severer financial constraints compared with large companies.

Chinese scholars have also studied the financing constraints and corporate investment from different perspectives, and have got different conclusions. Feng (1999) uses a data of 135 manufacturing enterprises listed on the Shanghai and Shenzhen Stock Exchange in 19951997 years, and divides the sample firms into two groups- 
the enterprises with financing constraints and the enterprises without financing constraints. He empirically analyzes the impact of internal cash flow on corporate investment. It is found that the influence of the internal cash flow on the investment of the enterprise mainly exists in the enterprises with financing constraints, and the enterprises without financing constraints show a decline of investment cash flow sensitivity. Wei and Liu (2004) take 222 manufacturing enterprises in the year 1998-2002 as a sample, and empirically analyze the relationship between financing constraints, uncertainty and corporate investment. The research shows that the financing constraints and investment cash flow sensitivity have a significant positive correlation, environment uncertainty and corporate investment behavior have a significant positive correlation, and the financing constraints positively mitigate the effect of the firm's uncertainty on the investment behavior. Then, some scholars introduce agency theory and behavioral finance into the field of corporate finance, and analyze the effect of agency costs, corporate governance and overconfidence of managers on corporate investment behavior (Tang, Zhu, \& Ma, 2007; Wang, 2008; Zhao, Xu, \& Ding, 2018).

Table 1: Summary of Literature Review

\begin{tabular}{|c|c|}
\hline Hansen(1999) & $\begin{array}{l}\text { It finds that there are two threshold values } \\
\text { and the financing constraints have changed } \\
\text { with time. At the same time, the enterprises } \\
\text { that are more financially constrained exhibit } \\
\text { significantly greater sensitivities than } \\
\text { enterprises that are less financially } \\
\text { constrained. }\end{array}$ \\
\hline Cleary(1999) & $\begin{array}{l}\text { The higher the corporate reputation (Z-score } \\
\text { value), the more sensitive is corporate } \\
\text { investment to internal capital, that is, } \\
\text { corporates with lower financing constraints } \\
\text { are more sensitive to investment cash flow. }\end{array}$ \\
\hline Feng(1999) & $\begin{array}{l}\text { It is found that the influence of the internal } \\
\text { cash flow on the investment of the enterprise } \\
\text { mainly exists in the enterprises with financing } \\
\text { constraints, and the enterprises without } \\
\text { financing constraints show a decline of } \\
\text { investment cash flow sensitivity. }\end{array}$ \\
\hline Love(2003) & $\begin{array}{l}\text { In countries with less developed financial } \\
\text { systems, companies usually face more } \\
\text { serious financing constraints, distorting its } \\
\text { investment behavior. Financial development } \\
\text { can help ease the financing constraints, } \\
\text { leading to regional economic growth. }\end{array}$ \\
\hline Almeida(2004) & $\begin{array}{l}\text { The cash flow sensitivity of cash is positive } \\
\text { and significantly different from zero for } \\
\text { constrained firms and smaller companies } \\
\text { tend to have lower information transparency } \\
\text { and severer financial constraints compared } \\
\text { with large companies. }\end{array}$ \\
\hline
\end{tabular}

\begin{tabular}{|l|l|}
\hline Wei and Liu & $\begin{array}{l}\text { There is a significant positive correlation } \\
\text { between the firm-specific uncertainty and the } \\
\text { investment behavior of the Chinese } \\
\text { manufacturing public companies. The overall } \\
\text { uncertainty has a positive relationship with } \\
\text { the investment behavior, and the market } \\
\text { uncertainty is negatively related to the } \\
\text { investment behavior, but it is not significant. } \\
\text { Financing constraints reduce the impact of } \\
\text { uncertainty on corporate investment behavior } \\
\text { to a certain extent. }\end{array}$ \\
\hline
\end{tabular}

Most of the above studies use group method to analyze the effect of financing constraints on corporate investment. There are some limitations in the research design. On the one hand, it is easy to bring into the endogenous problem according to the grouping of the financial variables, and on the other hand, it lacks the quantitative analysis on the relationship between the financing constraints and corporate investment efficiency. Lian and Su (2009) use the heterogeneous stochastic frontier model to examine the relationship between financing constraints, uncertainty and investment behavior, but they do not distinguish the differences between corporates of different property rights and corporates from different institutional environment. They only examine the effect of firm size on the financing constraints, uncertainty and investment efficiency. This paper examines the factors affecting financing constraints and uncertainties, as well as the evolution of the investment efficiency from the perspective of institutional environment and corporate heterogeneity, thus broadening extant literature.

In terms of heterogeneity, this paper focuses on the impact of firm size and property rights on investment efficiency. The financing constraints of large companies are lower and it is easier for them to obtain external funds to invest in projects. The efficiency of investment of large companies may be higher because they have a long history, higher information transparency, higher level of corporate governance, and often more assets that can be used as mortgages when applying for loans. Compared with nonstate-owned enterprises, the state-owned enterprises are often easier to apply for loans. First, the government can offer subsidies and assistance when state-owned enterprises have financial difficulties. With the interference of the government in the rationing of credit funds, the stateowned enterprises are easier to get the bank loans. The financing constraints facing state-owned enterprises are lower, and the investment efficiency may be more effective. Thus, it is hypothesized that:

H1a: Firm size has direct positive impact on corporate investment efficiency. 
H1b: Nature of property right is significantly related to corporate investment efficiency.

In terms of institutional environment, this paper takes the level of regional financial development as an alternative indicator to measure the influence of institutional environment on the financing constraints and investment efficiency of the company. The development of regional finance has increased the supply of funds. Borrowers are more likely to get funds to engage in high-risk projects, put into practice high risk and high yield projects that might have been abandoned, which will lead to an increase in the investment expenditure of the enterprise. Information asymmetry is less severe in areas with sound financial systems, and banks are easier to obtain the information of the lenders and their investment projects, and assess lender quality more accurately in order to make higher quality credit decisions, improve the credit efficiency and resource allocation efficiency. The development of regional finance can not only reduce the information acquisition cost, but also reduce the supervision cost, thus alleviating the financing constraints of enterprises and promoting the efficiency of corporate investment. Therefore, this study suggests that regional financial development has a significant positive correlation with corporate investment efficiency. Thus, it is hypothesized that:

H2: There is a significant positive correlation between regional financial development and corporate investment efficiency.

\section{Methods}

\subsection{Date and Sample}

The current research used a dataset of listed companies in China. Among listed companies, we excluded financial enterprises, ST companies (companies under special treatment because of their problematic business performance) and PT companies. In order to eliminate the impact of mergers and acquisitions on the results, firms with total assets growth or sales growth exceeding $200 \%$ were excluded. And we excluded the firms whose asset values are less than issued debts and the firms which issue $B$ shares and $\mathrm{H}$ shares at the same time. In order to avoid the impact of extreme values, firms with investment opportunities $>10$ or $<0$, investment capital ratio $>30$ or $<0$ were excluded. The main continuous variables in this paper are winsorized at $1 \%$ level. In the end, 895 listed companies were retained, with a total of 10064 observations. The data in the paper is drawn from China Stock Market \& Accounting Research Database (CSMAR database). Data processing is completed by Stata11.0 software. The definition and calculation method of the main variables are shown in Table 2.

The dependent variable of this research is corporate investment efficiency. It is the difference between actual investment expenditure and target investment expenditure. Drawing on the results of Lian and Su (2009), we calculate it based on the heterogeneity stochastic frontier model.

TOBIN, i.e. Tobin's $Q$, is used to measure corporate investment opportunities, which is the ratio of corporate market value to the replacement cost of assets (Brainard \& Tobin, 1968; Tobin, 1969). Tobin (1969) holds that when a firm's Tobin's $Q$ is greater than 1 , it will increase investment until Tobin's $Q$ is equal to 1 .

Financing constraints are measured by cash flow, equity financing increase, debt financing increase, firm size and property right. Cash flow reflects a firm's internal financing capacity, and it is indicated by the net cash flow generated by the operating activities divided by the net value of opening balance of fixed assets (Fazzari et al., 1988).

The increase of equity financing reflects the ability of external financing, i.e. the impact of stock market on corporate financing. It is the increase of capital stock plus capital reserves divided by total assets (Lian \& Su, 2009).

The increase in debt ratio will increase the probability of a company's bankruptcy and raise the cost of financing, so debt financing reflects the degree of financing constraints faced by the company (Hansen, 1999). It is indicated by the increase of total liabilities divided by total assets.

The size of a company is a key variable that affects corporate financing constraints. It is indicated by the natural logarithm of total assets. The degree of financing constraints faced by large companies is relatively low (Gilchrist \& Himmelberg, 1995).

In a special institutional environment such as China, there is a natural relationship between state-owned enterprises and state-owned banks. The state-owned enterprises usually do not face serious problems of financing constraints. Therefore, the nature of property rights can be used as an indicator to divide the difference of corporate financing capacity. It is indicated by a dummy variable, assigned 1 if state-owned and 0 if private (Qian, 1994; Konai, 1998).

Financial development level affects corporate investment efficiency by influencing corporate financing constraints, and it is indicated by the marketization index of financial industry (Fang, 2017). 
Table 2: Operational Definitions of Variables

\begin{tabular}{|l|l|l|}
\hline \multicolumn{1}{|c|}{ Variables } & \multicolumn{1}{c|}{ Initials } & \multicolumn{1}{c|}{ Operational Definitions } \\
\hline Investment Efficiency & IEI & $\begin{array}{l}\text { The difference between actual investment expenditure and target investment expenditure, } \\
\text { IEI = INVT - INVT* 1=vit- } \mu \text { it }\end{array}$ \\
\hline Investment Expenditure & INVT & $\begin{array}{l}\text { Cash paid to acquire fixed assets, intangible assets and other long-term assets / Opening balance } \\
\text { of Net value of fixed assets }\end{array}$ \\
\hline Investment Opportunities & TOBIN & Total Market Value / Asset Replacement Cost \\
\hline Cash Flow & CFlow & Operating Net Cash Flow / Opening balance of Net Value of Fixed Assets \\
\hline Equity Financing & EQUI & $\Delta$ (Capital Stock + Capital Reserves) / Total Assets \\
\hline Debt Financing & DEBT & $\Delta$ Total Liabilities / Total Assets \\
\hline Firm Size & SIZE & The natural logarithm of total asset \\
\hline Corporate Equity & SOE & Dummy variable. State-owned enterprises take 1, otherwise it is 0. \\
\hline $\begin{array}{l}\text { Level of Financial } \\
\text { Development }\end{array}$ & INDEX & $\begin{array}{l}\text { The marketization index of the financial industry is drawn from Fan Gang's "marketization index of } \\
\text { China's sub provinces 2011" and "China's sub provincial marketization index report 2016". }\end{array}$ \\
\hline
\end{tabular}

Notes: $1 . \mathrm{NVT}^{*}$ is the target value of investment expenditure, that is, the optimal investment expenditure, and $\varepsilon_{\mathrm{it}}$ is the disturbance item. It consists of two parts: the stochastic disturbance $\left(v_{i t}\right)$ and the financing constraints $\left(u_{i t}\right)$.

2. Since the "marketization index of the financial industry" was only issued in 2014, the data in 2015 and 2016 were replaced by 2014 data.

\subsection{Heterogeneous stochastic frontier model}

According to the previous literature (Aigner, 1977; Tao \& Wang, 2011), the basic form of stochastic frontier model is as follows:

$$
\ln y_{i}=\beta_{0}+\sum_{1}^{n} \beta_{n} x_{n i}+v_{i t}-u_{i t}
$$

The object of this research is investment efficiency, so $y_{i}$ is the corporate investment expenditure-INVT, $x_{n i}$ is the investment opportunity-TOBIN which is used to measure the company's optimal investment expenditure. $v_{i t}$ is the stochastic disturbance. If It follows the normal distribution, the $u_{i t}$ is used to measure the influence of the financing constraint on the investment efficiency. If it follows truncated half-normal distribution, that is $u_{i t} \sim \mathrm{N}+\left(\omega_{\mathrm{it}}, \sigma_{\mathrm{it} 2}\right)$. The heterogeneity of $u_{i t}$ as follows:

$$
\begin{aligned}
& \omega_{i t}=\exp \left(a_{0}+a_{1} \text { CFlow }+a_{2} \text { SIZE }+a_{3} E Q U I+a_{4} \text { DEBT }\right) \\
& \sigma_{i t}=\exp \left(B_{0}+B_{1} \text { CFlow }+B_{2} \text { SIZE }+B_{3} \text { EQUI }+B_{4} \text { DEBT }\right)
\end{aligned}
$$

By using the maximum likelihood estimate, we can quantitatively analyze the efficiency loss caused by the financing constraints. In addition, in order to study the level of regional financial development and the impact of corporate heterogeneity on the efficiency of the company, the sample is grouped in accordance with the level of regional financial development and company heterogeneity, and the investment efficiency of the company is calculated in groups. And then we analyzed the investment efficiency of each group.

\section{Analysis and Results}

\subsection{Descriptive Statistics of Variables}

Table 3 shows the descriptive statistics of the main variables. From this table, we can see that the mean value of INVT is 0.359 , the minimum value is 0 , the maximum value is 27.70 , and the investment expenditure of different companies is quite different. The mean of SIZE is 21.94 , the variance is 1.215 , and the scale difference of sample firms is small. The mean value of SOE is 0.695 , which indicates that $69.5 \%$ of the samples are state-owned enterprises. The mean value of INDEX is 7.616 , the minimum value is 0.120 , the maximum value is 12.01 , indicating that the financial development level in different regions is very uneven, and differences between regions are quite large.

Table 3: Descriptive Statistics

\begin{tabular}{|c|c|c|c|c|c|c|}
\hline Variables & $\mathbf{N}$ & Mean & Variance & Minimum & Median & Maximum \\
\hline INVT & 10064 & 0.359 & 1.050 & 0 & 0.163 & 27.70 \\
\hline TOBIN & 10064 & 1.782 & 1.085 & 0.684 & 1.395 & 9.833 \\
\hline CFlow & 10064 & 0.197 & 0.668 & -1.524 & 0.170 & 1.885 \\
\hline SIZE & 10064 & 21.94 & 1.215 & 18.16 & 21.82 & 27.10 \\
\hline EQUI & 10064 & 0.0220 & 0.082 & -0.113 & 0 & 0.501 \\
\hline DEBT & 10064 & 0.0750 & 0.165 & -0.292 & 0.045 & 0.740 \\
\hline SOE & 10064 & 0.695 & 0.460 & 0 & 1 & 1 \\
\hline INDEX & 10064 & 7.616 & 1.942 & 0.120 & 7.580 & 12.01 \\
\hline
\end{tabular}

\subsection{The Results of Heterogeneous Stochastic Frontier Model}

Table 4 reports the results of the heterogeneity stochastic frontier model. Model 1 is the result of the total sample 
estimation, and Model 3 is the result of Lian and Su (2009). In order to compare the empirical results with Lian and Su (2009) who uses a sample of firms listed in 2000-2006, this paper estimates Model 2 with the sample interval of 20032006 years. The coefficient of In_TOBIN is positive and significant at the level of $1 \%$ in both Model 1 and Model 2. In the financing constraints equation, the coefficients of CFlow, SIZE, EQUI, and DEBT are significantly negative at the level of $1 \%$, which are in agreement with the estimated results of Lian and Su (2009). This shows that investment opportunities and financing constraints are still the main factors affecting the investment behavior of listed companies in China. The increase of cash flow, the increase of equity financing and the increase of debt financing will help to alleviate the financing constraints. In addition, financing constraints faced by large companies are less serious.

The financing uncertainty equation in Model 1 , is not consistent with the estimation results of Lian and Su (2009). The coefficient of EQUI is significantly positive at the level of $5 \%$, while the coefficient of EQUI in model 2 is not significant. This shows that with the development of China's capital market and the increasingly strict supervision over securities market, it is difficult for listed companies to obtain equity financing through additional issuance and distribution, and the increase in equity financing deteriorated the uncertainty of subsequent financing.

Table 4: Estimation Results of Heterogeneous Stochastic Frontier Model

\begin{tabular}{|c|c|c|c|}
\hline & $\begin{array}{c}\text { Model1 } \\
(2003-2016)\end{array}$ & $\begin{array}{c}\text { Model } 2 \\
(2003-2006)\end{array}$ & $\begin{array}{l}\text { Model } 3 \\
\text { (Lian \& Su } \\
\text { 2009) }\end{array}$ \\
\hline \multicolumn{4}{|c|}{ Investment Function: } \\
\hline \multirow[t]{2}{*}{ In_TOBIN } & $0.421^{* * *}$ & $0.566^{\star \star *}$ & $0.421^{\star \star *}$ \\
\hline & $(10.80)$ & $(4.96)$ & $(4.56)$ \\
\hline Annual Effect & Control & Control & Control \\
\hline \multirow[t]{2}{*}{ cons } & $-0.420^{* * *}$ & $-0.376^{\star \star *}$ & -0.125 \\
\hline & $(-4.89)$ & $(-3.84)$ & $(-1.31)$ \\
\hline \multicolumn{4}{|c|}{ Financing Constraints: } \\
\hline \multirow[t]{2}{*}{ CFlow } & $-0.269^{* * *}$ & $-0.498^{* * *}$ & $-0.288^{* * *}$ \\
\hline & $(-12.81)$ & $(-9.11)$ & $(-7.67)$ \\
\hline \multirow[t]{2}{*}{ SIZE } & $-0.193^{* * *}$ & $-0.165^{* * *}$ & $-0.048^{* * *}$ \\
\hline & $(-10.05)$ & $(-4.16)$ & $(-3.12)$ \\
\hline \multirow[t]{2}{*}{ EQUI } & $-2.610^{\star * *}$ & $-4.240^{* * *}$ & $-4.785^{\star * *}$ \\
\hline & $(-8.99)$ & $(-4.07)$ & $(-4.90)$ \\
\hline \multirow[t]{2}{*}{ DEBT } & $-3.446^{\star * *}$ & $-4.515^{\star \star \star}$ & $-5.345^{\star \star *}$ \\
\hline & $(-20.79)$ & $(-12.20)$ & $(-14.36)$ \\
\hline \multirow[t]{2}{*}{ cons } & $5.817^{\star \star *}$ & $5.284^{\star * *}$ & 2.744 \\
\hline & $(12.91)$ & $(5.86)$ & $(2.84)$ \\
\hline \multicolumn{4}{|c|}{ Financial Uncertainty: } \\
\hline \multirow[t]{2}{*}{ CFlow } & $-0.572^{* * *}$ & $-0.271^{* * *}$ & $-0.105^{* * *}$ \\
\hline & $(-4.64)$ & $(-3.06)$ & $(-4.14)$ \\
\hline
\end{tabular}

\begin{tabular}{|c|c|c|c|}
\hline SIZE & $-0.966^{* * *}$ & $-0.693^{* * *}$ & $-0.459^{* * *}$ \\
\hline & $(-9.53)$ & $(-6.07)$ & $(-7.33)$ \\
\hline EQUI & $1.419^{* *}$ & 1.219 & 1.118 \\
\hline & $(2.08)$ & $(1.15)$ & $(1.62)$ \\
\hline DEBT & $1.369^{* * *}$ & $1.753^{* * *}$ & $1.295^{* *}$ \\
\hline & $(3.51)$ & $(5.69)$ & $(6.28)$ \\
\hline cons & $19.786^{* * *}$ & $14.598^{* * *}$ & $9.958^{* * *}$ \\
\hline & $(9.76)$ & $(6.32)$ & $(7.58)$ \\
\hline $\mathrm{N}$ & 10064 & 3073 & 4212 \\
\hline Log likelihood & -15855.9 & -4677.9 & -6371.6 \\
\hline Wald chi ${ }^{2}$ & 302.52 & 66.68 & 871.05 \\
\hline P-value & 0.000 & 0.000 & 0.000 \\
\hline
\end{tabular}

Note: ${ }^{* * *},{ }^{* * *}, \quad{ }^{*}$ respectively indicate significance level at $1 \%, 5 \%$, $10 \%$.

As companies with different property rights are often faced with different degree of financing constraints, this paper divides the sample firms into two groups (state-owned and non-state-owned) according to property rights, and the results are shown in Table 5 . It can be seen from the table that the coefficients of CFlow, SIZE, EQUI, and DEBT are significantly negative at the level of $1 \%$ for both state-owned and non-state-owned enterprises. This shows that the increase in cash flow, the expansion of enterprises, the increase of equity financing and the increase of debt financing will help to ease the financial restraint of stateowned enterprises and non-state-owned enterprises. In the financing uncertainty equation, the coefficient of CFlow and SIZE are significantly negative, but the coefficient of EQUI is not significant, and the coefficient of DEBT is only significant for the non-state-owned group. This may be due to the fact that the impact of equity financing on financing uncertainty are different between state-owned enterprises and nonstate-owned enterprises. In fact, when dummy variable SOE is introduced into the financing uncertainty equation, the coefficient of SOE is significantly negative at the level of $1 \%$, which indicates that the increase in equity financing of nonstate-owned enterprises will bring greater uncertainty in the follow-up financing (due to the limitation of passage length, the results are not reported in the article). The coefficient of DEBT in the financing uncertainty equation is negative and significant, which means that the increase of debt financing has reduced the current financing constraints of non-stateowned enterprises, while the possibility of debt financing in the future will be smaller and the uncertainty will be increased. Government implicit guarantee may make stateowned enterprises easier to obtain loans from the banks, even if they increase debt in current period, it has only a trivial impact on debt financing in the future. 
Table 5: Estimation Results of Property Rights Grouping

\begin{tabular}{|c|c|c|}
\hline & State-owned group & Private group \\
\hline \multicolumn{3}{|c|}{ Investment Function: } \\
\hline In_TOBIN & $0.367^{* * *} \quad(7.81)$ & $0.416^{* * \star}(5.78)$ \\
\hline Annual Effect & Control & Control \\
\hline cons & $-0.654^{* * *}(-8.35)$ & $(1.09)$ \\
\hline \multicolumn{3}{|c|}{ Financing Constraints: } \\
\hline CFlow & $-0.405^{\star \star \star}(-12.48)$ & $-0.160^{* \star *}(-4.75)$ \\
\hline SIZE & $-0.203^{* * *}(-9.65)$ & $-0.272^{* * *}(-7.83)$ \\
\hline EQUI & $-2.587^{\star * *}(-7.00)$ & $-2.240^{* * *}(-6.18)$ \\
\hline DEBT & $-3.600^{* * *}(-18.86)$ & $-2.797^{* * *}(-9.94)$ \\
\hline cons & $5.886^{\star * *}(12.40)$ & $8.066^{* * *}(9.58)$ \\
\hline \multicolumn{3}{|c|}{ Financial Uncertainty: } \\
\hline CFlow & $-1.056^{* * *}(-4.11)$ & $-0.325^{* * *} \quad(-2.95)$ \\
\hline SIZE & $-0.606^{* \star *}(-5.82)$ & $-0.882^{* * *} \quad(-6.86)$ \\
\hline EQUI & $0.267 \quad(0.15)$ & $(1.33)$ \\
\hline DEBT & -0.984 & $2.387^{* * *}(5.77)$ \\
\hline cons & $11.888^{* * *}(5.37)$ & $18.279^{* * *}(7.07)$ \\
\hline $\mathrm{N}$ & 6999 & 3065 \\
\hline Log Likelihood & -10617.2 & -5145.2 \\
\hline${\text { Wald } \mathrm{chi}^{2}}^{2}$ & 217.71 & 97.21 \\
\hline P-value & 0.000 & 0.000 \\
\hline
\end{tabular}

Note: ${ }^{* * *},{ }^{* * *},{ }^{*}$ respectively indicate significance level at $1 \%, 5 \%, 10 \%$.

In order to study the impact of institutional environment on the financing constraints and investment efficiency of listed companies, this paper divides the samples into low, medium and high groups according to the region financial development level. Table 6 reports the estimation results of stochastic frontier models. It can be seen from the table that in the financing constraint equation, the coefficient of SIZE is significantly negative in the "high level of financial development", and in the other two groups it is not significant. This may be due to the sufficient competition in the financial markets with high financial development level, where the good governance mechanism of large enterprises can give full play, and the financing constraints of large enterprises could be alleviated. In the areas of low level of financial development, whether the enterprise can obtain external financing depends more on its political connection, the establishment of the relationship between banks and enterprises and so on. Firm size has little effect on the financing constraints.

In the financing uncertainty equation, the coefficient of CFlow is significantly negative in the group of "low level of financial development level" and "medium level of financial development", but it is not significant in the group of "high level of financial development". This shows that the incremental cash flow impacts the financing of enterprises which are located in regions lagging behind in the construction of financial systems and helps to alleviate the uncertainty of the enterprises' follow-up financing, but when the financial market develops to a certain extent, the dependence of the enterprise on internal financing is reduced, and whether the cash flow increases or not has little effect on the follow-up financing of the enterprise. The coefficient of EQUI and DEBT is significantly negative in the group of "low level of financial development", while the coefficient in the "high level of financial development" and "medium level of financial development" are significantly positive. The reason for this difference may be that in areas with higher financial development level, the degree of marketization is higher and firms operates in a more transparent environment. The increase of equity financing and debt financing increases the risks of the enterprise, leading the capital market or the banking industry to doubt about the subsequent refinancing of the enterprise. So the uncertainty of subsequent financing will be increasing. In the regions where the financial system is not sound, the degree of marketization is low and the transparency of information is poor. Once the enterprise obtains equity financing or debt financing, it will mean that the enterprise has good governmententerprise or banks-enterprises relationship. With this "relationship", they can solve the subsequent refinancing, so the financing uncertainty has not increased but decreased.

Table 6: Estimation Results of Region Financial Development Level Grouping

\begin{tabular}{|c|c|c|c|}
\hline & Low & Medium & High \\
\hline \multicolumn{4}{|c|}{ Investment Function: } \\
\hline \multirow[t]{2}{*}{ In_TOBIN } & $0.437^{* * *}$ & $0.382^{* * *}$ & $0.364^{* * *}$ \\
\hline & $(5.84)$ & $(6.87)$ & $(5.04)$ \\
\hline Annual Effect & Control & Control & Control \\
\hline \multirow[t]{2}{*}{ cons } & $-0.582^{* * *}$ & $-0.415^{\star * *}$ & -0.044 \\
\hline & $(-4.71)$ & $(-3.92)$ & $(-0.29)$ \\
\hline \multicolumn{4}{|c|}{ Financing Constraints: } \\
\hline \multirow[t]{2}{*}{ CFlow } & $-0.277^{* * *}$ & $-0.239^{* * *}$ & $-0.275^{\star * *}$ \\
\hline & $(-2.98)$ & $(-5.61)$ & $(-7.60)$ \\
\hline \multirow[t]{2}{*}{ SIZE } & -0.275 & -0.030 & $-0.225^{\star * *}$ \\
\hline & $(-1.44)$ & $(-0.86)$ & $(-7.03)$ \\
\hline \multirow{2}{*}{ EQUI } & $-1.674^{\star * *}$ & $-3.719^{* * *}$ & $-2.823^{* * *}$ \\
\hline & $(-3.22)$ & $(-5.98)$ & $(-3.84)$ \\
\hline \multirow[t]{2}{*}{ DEBT } & $-4.843^{* * *}$ & $-4.754^{* * *}$ & $-3.434^{* * *}$ \\
\hline & $(-6.90)$ & $(-13.36)$ & $(-10.37)$ \\
\hline \multirow[t]{2}{*}{ cons } & 6.842 & $2.316^{* * *}$ & $6.765^{* * *}$ \\
\hline & $(1.61)$ & $(2.71)$ & $(8.94)$ \\
\hline \multicolumn{4}{|c|}{ Financial Uncertainty: } \\
\hline \multirow[t]{2}{*}{ CFlow } & $-0.450^{* * *}$ & $-0.149^{* *}$ & -0.102 \\
\hline & $(-4.01)$ & $(-2.40)$ & $(-1.32)$ \\
\hline \multirow[t]{2}{*}{ SIZE } & $-0.298^{*}$ & $-0.583^{* * *}$ & $-0.498^{\star * *}$ \\
\hline & $(-1.77)$ & $(-9.00)$ & $(-5.01)$ \\
\hline \multirow[t]{2}{*}{ EQUI } & $-5.056^{\star * *}$ & $1.208^{* *}$ & $2.338^{* * *}$ \\
\hline & $(-4.13)$ & $(2.42)$ & $(3.48)$ \\
\hline \multirow[t]{2}{*}{ DEBT } & $-1.873^{\star *}$ & $0.926^{* * *}$ & $1.764^{* * *}$ \\
\hline & $(-2.30)$ & $(3.66)$ & $(5.13)$ \\
\hline \multirow[t]{2}{*}{ cons } & $7.015^{*}$ & $12.716^{* * *}$ & $10.439^{\star * *}$ \\
\hline & $(1.91)$ & $(9.36)$ & $(5.11)$ \\
\hline $\mathrm{N}$ & 2678 & 4239 & 3147 \\
\hline Log Likelihood & -4355.9 & -6542.9 & -4925.0 \\
\hline Wald chi ${ }^{2}$ & 141.06 & 135.64 & 93.15 \\
\hline P-value & 0.000 & 0.000 & 0.000 \\
\hline
\end{tabular}

Note: ${ }^{* * *},{ }^{* * *},{ }^{*}$ respectively indicate significance level at $1 \%, 5 \%, 10 \%$. 


\subsection{Statistical Analysis of Investment Efficiency}

Based on the stochastic frontier analysis, this paper quantitatively analyzes the present situation, evolution and influencing factors of the investment efficiency of listed companies in China. Figure 1 shows the frequency distribution of sample firms' investment efficiency between 2003 to 2016. The figure shows that the investment efficiency of listed companies in China is obviously right deviated, the IEI mean value is 0.745 and the standard deviation is 0.103 , which is $3.62 \%$ higher than that the result of Lian and Su (2009). It means that the capital market has improved after more than ten years' development. However, the financing constraints have not been fundamentally solved yet. The investment efficiency needs to be further improved.

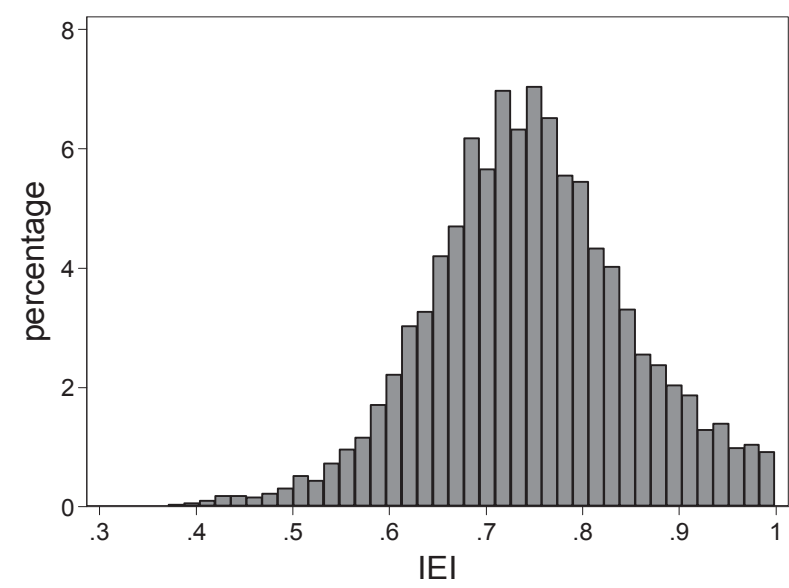

Data sources: IEI is calculated by the authors on the basis of the heterogeneity stochastic frontier model with data from CSMAR database.

Figure 1: Investment Efficiency of Listed Companies' Frequency Distribution

In order to analyze the effect of company heterogeneity and institutional environment on the efficiency of the company investment, this paper divides the samples into groups according to the size of the company, property rights and region financial development level, and calculated the investment efficiency of different categories of listed companies and performed t-test. The results are shown in Table 7.
Table 7: Differences of Listed Companies' Investment Efficiency

\begin{tabular}{|c|c|c|c|c|c|}
\hline \multicolumn{2}{|c|}{ Group } & $N$ & $\begin{array}{c}\text { Mean } \\
\text { (Median) }\end{array}$ & $\begin{array}{c}\text { Difference } \\
\text { (t-value) }\end{array}$ & $\begin{array}{c}\text { P- } \\
\text { value }\end{array}$ \\
\hline \multirow{3}{*}{ Firm Size } & Large & 3354 & $\begin{array}{c}.807 \\
(.801)\end{array}$ & \multirow{3}{*}{$\begin{array}{c}.092 \\
(-46.36)\end{array}$} & \multirow{3}{*}{0.000} \\
\hline & $\begin{array}{c}\text { Medium } \\
\text {-sized }\end{array}$ & 3359 & $\begin{array}{l}.744 \\
(.742)\end{array}$ & & \\
\hline & Small & 3351 & $\begin{array}{l}.685 \\
(.688)\end{array}$ & & \\
\hline \multirow{2}{*}{$\begin{array}{c}\text { Property } \\
\text { Rights }\end{array}$} & $\begin{array}{l}\text { State- } \\
\text { owned }\end{array}$ & 6999 & $\begin{array}{l}.750 \\
(.746)\end{array}$ & \multirow{2}{*}{$\begin{array}{c}.015 \\
(-6.37)\end{array}$} & \multirow{2}{*}{0.000} \\
\hline & Private & 3065 & $\begin{array}{l}.735 \\
(.736)\end{array}$ & & \\
\hline \multirow{3}{*}{$\begin{array}{c}\text { Region } \\
\text { Financial } \\
\text { Development } \\
\text { Level }\end{array}$} & High & 3147 & $\begin{array}{l}.748 \\
(.745)\end{array}$ & \multirow{3}{*}{$\begin{array}{c}.004 \\
(-1.89)\end{array}$} & \multirow{3}{*}{0.059} \\
\hline & Medium & 4239 & $\begin{array}{c}.746 \\
(.745)\end{array}$ & & \\
\hline & low & 2678 & $\begin{array}{l}.740 \\
(.738)\end{array}$ & & \\
\hline
\end{tabular}

Note: Difference in the table is the difference between large and small corporates, difference between state-owned and private corporates, as well as difference between corporates in areas with high financial development level and that in areas with low financial development level.

In order to analyze the evolution of the investment efficiency of listed companies in China, this paper has drawn up a sequential diagram of the investment efficiency of different types of listed companies. Figure 2(a) is the difference and evolution of investment efficiency of differentsized companies. As is indicated in the graph, the investment efficiency of large companies increased from 0.772 in 2003 to 0.834 in 2016 and the investment efficiency increased by $8.03 \%$ in the thirteen year period. The investment efficiency of small enterprises increased from 0.681 in 2003 to 0.703 in 2016 . Although the rate of growth is lower than large enterprises, there is still a certain increase. It shows that China's capital market has achieved some achievements after more than 10 years' development. The banking industry has continuously launched a variety of credit policies to help private enterprises especially small and micro enterprises to solve financing difficulties in the last few years. The financing constraints faced by smallscaled companies have been alleviated, but the investment efficiency of small companies is still not optimistic.

Figure 2(b) is the evolution of investment efficiency of corporates of different nature of property rights. It shows that the investment efficiency of state-owned enterprises in China has been higher than that of private enterprises before 2014, but after 2014, especially in 2015, private enterprises' investment efficiency has risen abruptly, even surpassing the investment efficiency of state-owned 
enterprises. Because of the special property right structure of state-owned enterprises, it has always been easier for them to obtain bank loans. Financing constraints for stateowned enterprises are not as severe as private ones, contributing to their high investment efficiency. However, with the deepening of the market-oriented reform, the preferential policy for the state-owned enterprises has been gradually lost. Due to good governance structure of the private enterprises, financing constraints are gradually relieved and corporate investment efficiency is improving step by step.

Figure 2(c) is the differences and evolution of the investment efficiency of firms from different regions. It can be seen from the figure that investment efficiency is higher for firms located in regions where the level of financial development is high than those are located in regions where the level of financial development is low. In 2003, the investment efficiency of enterprises with high and low financial development level was almost the same. But by 2016, the investment efficiency has increased to 0.781 for firms which are located in regions where the financial development level is high. The average investment efficiency of the enterprises was 0.759 for firms which are located in regions that have lower financial development level, and the gap between them was gradually widening. It shows that the level of regional financial development, especially the development level of bank credit, has great impact on the investment efficiency of listed companies. It is very important to speed up the development of regional financial systems to reduce the gap of corporate investment efficiency between regions.

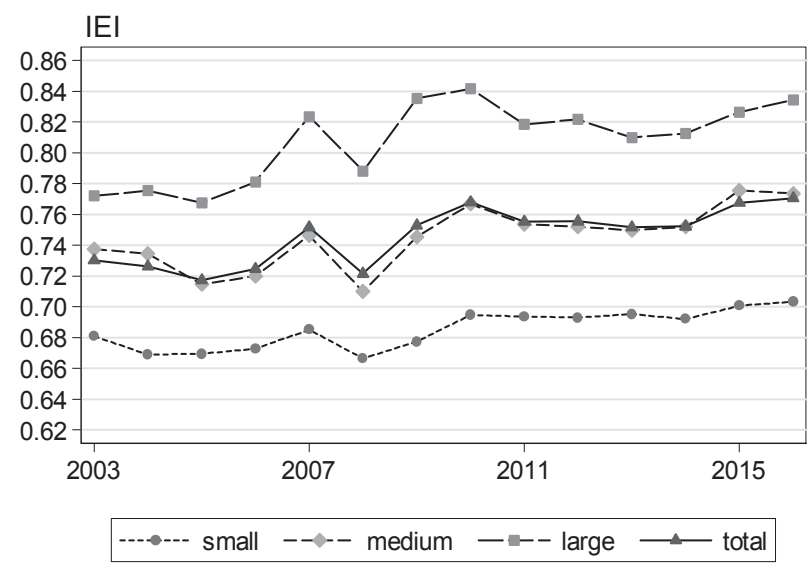

Figure 2(a): Listed Companies' Investment Efficiency of Different Sizes

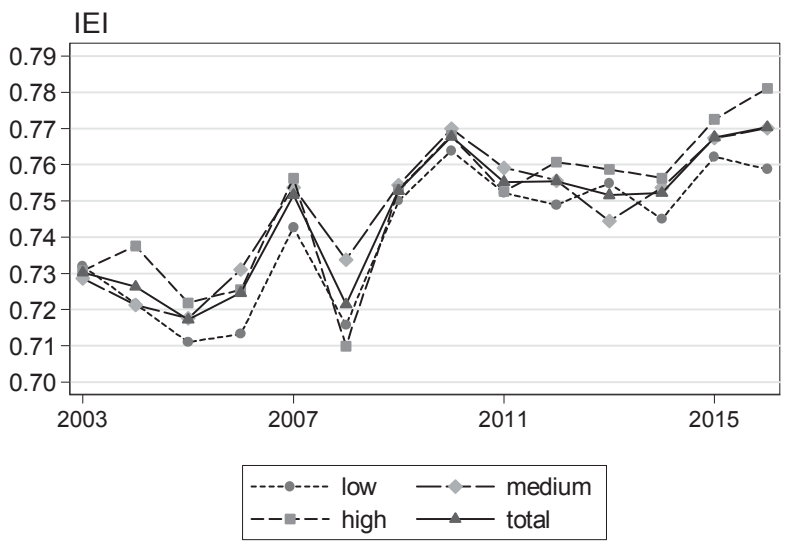

Figure 2(b): Listed Companies' Investment Efficiency of Different Property Rights

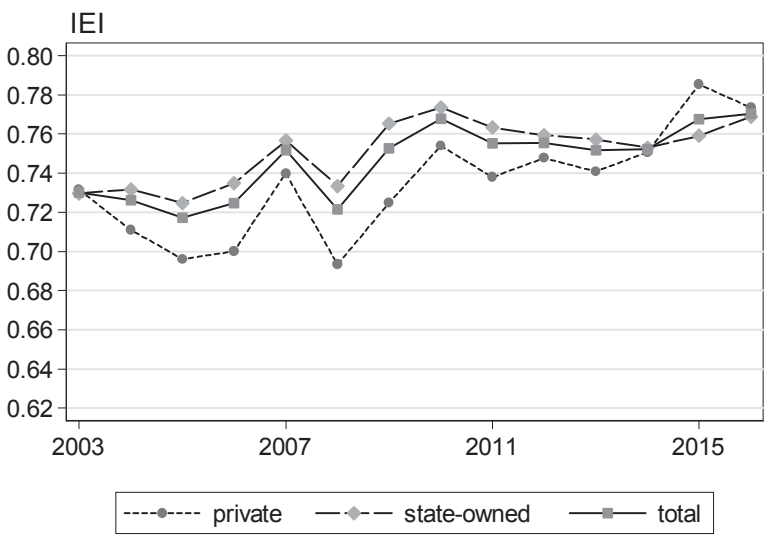

Data sources: IEI is calculated by the authors on the basis of the heterogeneity stochastic frontier model with data from CSMAR database.

Figure 2(c): Listed Companies' Investment Efficiency in Different Regions

\section{Conclusions}

This paper studies the current situation, evolution and influencing factors of the investment efficiency of China's $A$ listed companies between 2003 to 2016 by using the heterogeneous stochastic frontier model. The findings show that: (1) financing constraints are still an important factor affecting the investment efficiency of listed companies in China. After more than 10 years of development, the capital market has achieved some achievements, and the investment efficiency of the listed companies has improved, but compared with the target value, there are still more than $20 \%$ gaps. It is still a long way to go to alleviate the 
financing constraints of listed companies, especially for small and medium-sized enterprises and private enterprises. (2) Regional financial development affects corporate investment efficiency by affecting the financing constraints of listed companies. Thus, establishing and improving the financial market system as well as improving the information transparency will definitely contribute to the promotion of corporate investment efficiency. (3) Although the investment efficiency of different types of companies increased in 2016 compared to that in 2003 , the gap is gradually widening. Accelerating regional development, maintaining regional balance, narrowing differences among regions, industries and differences between public and private sectors are the top priority for deepening reform in emerging market.

The findings of this study indicate that policy makers should relax entry barriers in financial market and promote fair competition among banks in order to improve the financial environment of emerging markets and, consequently, lead to an increase in corporate investment efficiency and rational allocation of resources.

This study has several limitations. First, this paper studies the impact of regional financial development and corporate heterogeneity on corporate investment efficiency from the perspective of financing constraints. Previous studies have shown that agency cost is also a key factor affecting corporate investment behavior, and its influence is opposite to the influence of financing constraints. Thus, future research can bring the agency problem into the research framework, and study the impact of regional financial development on corporate investment behavior under the interaction of agent problem and financing constraints. Second, this research is conducted in a long-term longitudinal perspective. During the research period, other institutional environment changes may affect the conclusions of this paper. Future research can proceed from other external factors such as policy uncertainty and government intervention to study corporate investment behavior.

\section{References}

Acemoglu, D., \& Zilibotti, F. (1997). Was Prometheus Unbound by Chance? Risk, Diversification and Growth. Journal of Political Economy, 105(4), 709-775.

Aigner, D. J., Lovell, C. A. K., \& Schmidt, P. (1977). Formulation and Estimation of Stochastic Frontiers Production Function Models. Journal of Econometrics, 1(6), 21-37.

Almeida, H., Campello, M., \& Weisbach, M. S. (2010). The Cash Flow Sensitivity of Cash. Journal of Finance, 59(4), 1777-1804.
Brainard, W. C., \& Tobin, J. (1968). Pitfalls in Financial Model Building. American Economic Review, 58(2), 99122.

Cleary, S. (1999). The Relationship between Firm Investment and Financial Status. Journal of Finance, 54(2), 673-692.

Cummins, J. G., Hassett, K. A., \& Oliner, S. D. (2006). Investment Behavior: Observable Expectations, and Internal Funds. American Economic Review, 96(3), 796810.

Fazzari, S., Hubbard, G., \& Peterson, B. (1988). Financing Constraints and Corporate Investment. Brookings Papers on Economic Activity, 19(1), 141-195.

Feng, W. (1999). Internal Cash Flow and Corporate Investment - Evidence from Financial Reports of Listed Companies in China. Economic Science, 1, 51-57.

Gilchrist, S., \& Himmelberg, C. P. (1995). Evidence on the Role of Cash Flow for Investment. Finance \& Economics Discussion, 36(3), 541-572.

Greenwood, J., \& Jovanovic, B. (1990) Financial Development, Growth and the Distribution of Income. Journal of Political Economy, 98, 1076-1107

Hansen, B. (1999). Threshold Effects in Non-dynamic Panels: Estimation, Testing and Inference. Journal of Econometrics, 93(2), 345-368.

Kingr, G., \& Levine, R. (1993). Finance, Entrepreneurship and Growth: Theory and Evidence. Journal of Monetary Economics, 32, 513-542.

Kornai, J. (1998). The Place of the Soft Budget Constraint Syndrome in Economic Theory. Social Science Electronic Publishing, 26(1), 11-17.

Lian, Y. J., \& Su, Z. (2009). Financial Constraints, Uncertainty and Firms' Investment Efficiency. Management Review, 21(1). 19-25.

Love, I. (2003). Financial Development and Financing Constraints: International Evidence from the Structural Investment Model. Review of Financial Studies, 16(3), 765-791.

Min, C. \& Liu, Y.J. (2017). Investment Efficiency of Urban Infrastructure Systems: Empirical Measurement and Implications for China. Habitat international, 70, 91-102.

Modigliani, F., \& Miller, M. (1958). The Cost of Capital, Corporation Finance, and the Theory of Investment. The American Economic Review, 48(3), 261-297.

O'Toole, C. M., Morgenroth, E. L., \& Ha, T. T. (2016). Investment Efficiency, State-owned Enterprises and Privatisation: Evidence from Viet $\mathrm{Nam}$ in Transition. Journal of corporate finance; contracting, governance and organization, 37, 93-108.

Pawlina, G., \& Renneboog, L. (2005). Is Investment-Cash Flow Sensitivity Caused by Agency Costs or Asymmetric 
Information? Evidence from the UK. European Financial Management, (11), 483-513.

Qian, Y. (1994). A Theory of Shortage in Socialist Economics Based on the "Soft Budget Constraint". American Economic Review, 84(84), 145-156.

Son, S. H. (2015). A Study on the Cash Policies of Retail Firms. Journal of Distribution Science, 13(3), 69-77.

Tang, X.S., Zhu, X.S., \& Ma, R.J. (2007). Enterprise Internal Control: Scope, Nature and Concept Frame Work- Study Based on Enterprise System and Integer Effectiveness. Accounting Research, 7, 44-51.

Tao, C., Xie, L.M., \& Zhang, Y.Y. (2017). How does analysts' forecast quality relate to corporate investment efficiency? Journal of corporate finance; contracting, governance and organization, 43, 217-240.

Tao, C.Q., \& Wang, Z.P. (2011). Stochastic Frontier Approach Progress and Prospects. The Journal of Quantitative \& Technical Economics, 11, 148-160.

Tobin, J. (1969). A General Equilibrium Approach to Monetary Theory. Journal of Money Credit \& Banking, 1(1), 15-29.
Wang, X., Zhang, M., \& Yu, F.S. (2008). CEO Overconfidence and Distortion of Firms' Investments: Some Empirical Evidence from China. Nankai Business Review, 11(2), 77-83.

Wang, X.L., Fang, G., \& Yu, J.W. (2017). China's Sub Provincial Marketization Index Report (214-220). Beijing: Social Science Literature Press.

Wang, X.L., Bao, M.M., \& Zhang, L.T. (2014). Financial Development, Lending Behavior and Lending Efficiency: Empirical Evidence Based on Chinese City Commercial Banks. Journal of Financial Research, 7, 94-106.

Wei, F., \& Liu, X. (2004). Effect of Financing Constraints and Uncertainty on Enterprise Investment Behavior. Economic Science, 2, 35-42.

Yoon, B. H. (2014). A Study on the Financing Decision of Retail Firms Listed on Korean Stock Markets. Journal of Distribution Science, 8(3), 17-26.

Zhao, X., Xu, J., \& Ding, L.L. (2018). Research on Board Network, Governance Role of Independent Directors and Over Investment Behavior of Listed Companies. Journal of Audit \& Economics, 33(1), 69-80. 